International Journal of Social Science And Human Research

ISSN(print): 2644-0679, ISSN(online): 2644-0695

Volume 04 Issue 07 July 2021

DOI: 10.47191/ijsshr/v4-i7-38, Impact factor-5.586

Page No: 1832-1836

\title{
Legal Protection on Violations Related to Consumer Financial Services in Transactions Through the Phone Media (Study of Financial Services Authority Regulation Number 1/Pojk.07/2013)
}

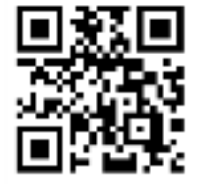

\author{
Sejahtera Giovani ${ }^{1}$ Jeane Neltje Saly $^{2}$ \\ ${ }^{1}$ Master of Law Program, Faculty of Law, State University of Veteran Jakarta \\ ${ }^{2}$ Lecturer of Postgraduate Masters in Law, State University of Veteran Jakarta
}

\begin{abstract}
This study discusses the study and research on legal consequences, legal protection, and legal remedies that consumers can take in carrying out transactions at financial service institutions carried out by telephone and are associated with the Financial Services Authority Regulation Number: 1/POJK.07/2013. This research is analytical descriptive research that describes legal protection efforts for consumers of Financial Services Institutions for violations in telephone transactions, using a normative juridical approach, namely reviewing and testing data based on secondary data, in the form of literature studies and supported by field studies, namely document examination, and analysis. Interview.
\end{abstract}

KEYWORDS: Financial Services Institutions, Legal Protection, Transaction Violations Through, Telephone

\section{INTRODUCTION}

Along with the opening of the Indonesian economy, which has been included in a free and open world trade system within the framework of the WTO, APEC, and especially AFTA, economic and financial management has gradually been handed over to the market economy. This inevitably requires the Indonesian economy to compete in the business world.

This has resulted in companies, nations, and countries being increasingly vulnerable to intense competition ${ }^{1}$. It also impacts national economic development, which must also be carried out in a transparent and accountable manner by referring to the principles of economic democracy as mandated by Pancasila and the 1945 Constitution of the Republic of Indonesia. The goal of a national economy that can grow stably and sustainably is to create job opportunities. that is broad and balanced in all sectors of the economy, as well as providing equitable welfare to all Indonesian people is national economic development that is carried out comprehensively and can drive national economic activities that have a broad reach and touch all real sectors of the Indonesian people's economy ${ }^{2}$.

To achieve this goal, the national economic development program needs to be supported by good governance, continuously reforming every component in the national economic system. One of the essential components in the national economic system is the financial system and all financial service activities that carry out the intermediary function for various productive activities in the national economy. As one of the efforts to support the process of achieving national economic goals and as a consequence of the implementation of the Letter of Intent (LOI) signed by the IMF and the Republic of Indonesia, the Financial Services Authority or OJK in short, which carries out functions as a regulator, supervisor, as well as protector of business actors. and consumers in the Indonesian financial sector ${ }^{3}$.

Coupled with the rapid development of science and technology in today's world, it has also impacted changes in human behavior, both socially, educationally, informationally, and trade transactions. One of them with the development and progress of telecommunications has encouraged progress in information technology.

The increasingly widespread use of telephones in business, industrial, and household activities has changed people's views. Physical activities initially monopolized the above activities. They have now shifted to activities that do not require physical activity.

In the globalization of telecommunications that is increasingly integrated with the increasing popularity of telephones and even with the emergence of mobile phone communication tools (mobile phones) as a basic need, it seems to have made the world increasingly narrow and increasingly fade state boundaries along with sovereignty and social order, as well as the development of

\footnotetext{
${ }^{1}$ Bungaran Saragih, Futures Exchange Prospects in Agricultural Development, BAPPEBTI, Jakarta, 2004, p. 19

${ }^{2}$ www.Hukumonline.com, October 2020.

${ }^{3}$ Ibid
} 


\section{Legal Protection on Violations Related to Consumer Financial Services in Transactions Through the Phone Media (Study of Financial Services Authority Regulation Number 1/Pojk.07/2013)}

technology and information in Indonesia. Any transaction of buying and selling goods that were initially conventional slowly turned into buying and selling goods electronically using telephone media.

In the world of trade, telecommunications and information technology have been utilized as a medium to expand marketing and facilitate transactions in trade transactions, which initially was a standard agreement in a transaction, namely in physical and written form or directly, it is evident that all parties meeting each other are now starting to be abandoned. Where an agreement and transaction do not meet directly or sign directly.

One form of transaction in the banking world that uses telecommunications technology is electronic transactions that are often used in the community offered by bank financial institutions. The presence of telephone service as an alternative medium in providing conveniences for customers of a bank has become a somewhat effective solution. This is inseparable from the advantages of the telephone itself, where everyone who wants to make transactions by telephone can do it anywhere and anytime, so the existence of the telephone creates a positive aspect in the form of time effectiveness and efficiency in transactions.

Apart from the positive aspects of transactions via telephone, transactions via telephone are also inseparable from the risks that exist in its implementation. Of course, it can also be realized that the negative aspects of this telecommunications system can also have a negative impact so that violations and crimes that were initially in conventional life cannot be found, now can easily be carried out by specific individuals or groups, resulting in such significant losses for the community. Moreover, even the State, especially losses for customers of a financial institution cannot be avoided, among others, the number of criminal acts of fraud on a transaction such as the rights and obligations of customers as offered or the details of a product offered is not the same or not following the reality, credit card burglary, and can also be used as a means of money laundering crimes. These various deviations require an effective legal system in preventing and overcoming various crimes that arise from using this telephone as a transaction medium. So that raises a question how is the conception of legal protection for customers of a financial institution, in this case, as consumers, if a transaction at the financial institution is carried out by telephone.

Furthermore, it can also be used as a means of money laundering crimes. These various deviations require an effective legal system in preventing and overcoming various crimes that arise from using this telephone as a transaction medium. So that raises a question how is the conception of legal protection for customers of a financial institution, in this case, as consumers, if a transaction at the financial institution is carried out by telephone. Moreover, it can also be used as a means of money laundering crimes. These various deviations require an effective legal system in preventing and overcoming various crimes that arise from using this telephone as a transaction medium. So that raises a question how is the conception of legal protection for customers of a financial institution, in this case, as consumers, if a transaction at the financial institution is carried out by telephone.

Consumer Protection is all efforts that guarantee legal certainty to protect consumers ${ }^{4}$. Consumer protection law or consumer law can be interpreted as the entire legal regulation that regulates the rights and obligations of consumers and producers that arise in their efforts to meet their needs. Thus, if consumer protection is defined as all efforts that guarantee the certainty of the fulfillment of consumer rights as a form of protection to consumers, then consumer protection law is the law that regulates efforts to ensure the realization of legal protection for the interests of consumers, within the framework of implementing consumer protection. and as part of implementing the realization of national economic goals, with the birth of the Financial Services Authority or briefly, OJK is expected to be very capable of acting and functioning as a regulator, and supervisor.

\section{PROBLEM FORMULATION}

What are the obstacles to the implementation of legal protection for consumers of financial services institutions for violations in telephone transactions based on the Financial Services Authority Regulation Number: 1/POJK.07/2013 concerning Consumer Protection in the Financial Services Sector?

How does the government make the efforts in implementing legal protection by the OJK on the implementation of transactions at financial service institutions that are carried out by telephone? By the Financial Services Authority Regulation Number: 1/POJK.07/2013 concerning Consumer Protection in the Financial Services Sector?

\section{RESEARCH METHODS}

The approach method used in this study is a normative juridical method, namely reviewing and testing data based on secondary data. The secondary data used in this study consists of primary legal materials in the form of laws and regulations relating to the issues studied, namely legal protection for consumers of financial services institutions against telephone transactions. Besides that, secondary legal materials are in the form of scientific articles from experts and some tertiary legal materials, where tertiary legal materials are materials that provide information about primary legal materials and secondary legal materials.

\footnotetext{
${ }^{4}$ Az. Nasution, Law and Consumers: A Socio-Economic and Legal Review on Indonesian Consumer Protection, Sinar Harapan Pustaka, Jakarta, 1995, p. 64
} 
Legal Protection on Violations Related to Consumer Financial Services in Transactions Through the Phone Media (Study of Financial Services Authority Regulation Number 1/Pojk.07/2013)

\section{THEORETICAL FRAMEWORK}

The research in the preparation of this thesis refers to the theoretical framework regarding the existence of the Consumer Protection Law and the Financial Services Authority (OJK) as a form of government intervention to protect consumers in dealing with Financial Services Businesses.

\section{Legal Protection Theory}

Fitzgerald quotes the term legal protection theory from Salmond that the law aims to integrate and coordinate various interests in society because, in traffic of interests, protection of specific interests can be done by limiting various interests on the other hand. The interest of the law is to take care of human rights and interests so that the law has the highest authority to determine human interests that need to be regulated and protected ${ }^{5}$.

Furthermore, according to Phillipus M. Hadjon, legal protection for people is preventive and responsive government action. Preventive legal protection aims to prevent disputes from occurring, which directs government actions to make decisions based on discretion. Responsive protection aims to prevent disputes from occurring, including their handling in the judiciary ${ }^{6}$.

From the expert's descriptions above, it provides an understanding that legal protection is a description of the workings of the legal function to realize legal objectives, namely justice, expediency, and legal certainty. Legal protection is a protection given to legal subjects by the rule of law, whether preventive or in a repressive form, both written and unwritten, in enforcing legal regulations.

\section{Consumer Protection Theory}

The principles regarding the position of consumers in relation with business actors are based on doctrines or theories known in the historical development of consumer protection law, among others:

a. Let the buyer beware (caveat emptor)

The doctrine of letting the buyer beware or caveat emptor is the basis for the birth of disputes in consumer transactions. This principle assumes that business actors and consumers are two very balanced parties not to need protection. This principle contains a weakness in the development of consumers. They do not receive adequate information to determine the choice of the goods and services they consume. This can be caused by the limited knowledge of consumers or the lack of openness of business actors to the products they offer. Thus, if the consumer suffers a loss, the business actor can argue that the loss results from the consumer's negligence.

b. The due care theory

This doctrine states that business actors must be careful in marketing products, both goods, and services. As long as business actors are careful with their products, they cannot be blamed. This principle applies to proof. Whoever postulates, then he is the one who proves it. This is by the spirit of proof in private law in Indonesia, namely the proof is with the plaintiff, by article $1865 \mathrm{BW}$ which expressly states that whoever argues has a right or to confirm his right or refute the rights of others, or refers to an event, then required to prove the existence of such rights or events.

c. The privilege of contract

This doctrine states that business actors must protect consumers, but this can only be done if there is a contractual relationship. Business actors cannot be blamed beyond what was agreed upon. Thus consumers can sue based on default. This is by the provisions in Article 1340 BW, which states that the scope of the agreement is only between the parties who agree $^{7}$.

\section{RESEARCH RESULTS AND DISCUSSION}

Discussing the barriers to legal protection for consumers of financial service institutions, it is inevitable that we cannot separate ourselves from Law Number 8 of 1999 concerning consumer protection because this law is used for consumer protection, including customers in general.

Consumer Protection in the financial services sector aims to create a reliable consumer protection system, increase consumer empowerment, and raise awareness of Financial Services Businesses regarding the importance of consumer protection to increase public confidence in the financial services sector.

The expected tangible results include, among others, Financial Services Businesses paying attention to the aspect of fairness in determining the cost or price of service products, minimum fee-based pricing that does not harm the Consumers, as well as the suitability of the products or services offered with the needs and abilities of the Consumers.

\footnotetext{
${ }^{5}$ Satjipto Raharjo, Legal Studies, Bandung: PT. Image of Aditya Bakti, 2000, p. 53

${ }^{6}$ Ibid, p. 54

${ }^{7}$ Shidarta, Indonesian Consumer Protection Law, PT. Grasiondo, Jakarta, 2006, p. 61
} 


\section{Legal Protection on Violations Related to Consumer Financial Services in Transactions Through the Phone Media (Study of Financial Services Authority Regulation Number 1/Pojk.07/2013)}

For consumers of financial service institutions in transactions over the telephone, apart from obtaining legal protection based on Law No. 8 of 1999 concerning Consumer Protection and Law No. 21 of 2011 concerning the Financial Services Authority, it is also regulated more precisely by the Regulation of the Financial Services Authority Number 1 / POJK. .07/2013 concerning Consumer Protection in the Financial Services Sector. From several examples of violations of telephone transactions by financial service institutions, such as offering financial service products over the phone or commonly called Telemarketing, the indications of violations include:

a. Offering banking or insurance products without explaining the benefits, characteristics, risks, and additional costs. In the future, there is the potential for disputes with customers who feel disadvantaged.

b. Financial Services Providers (PUJK) obtain Customer's data without the knowledge and approval of the Customer.

c. Offering several insurance products with the same benefits to customers.

d. Memories Service Providers (PUJK) offer a financial service product in the same package as other products (bundling product) where the Customer does not have the right to choose other services in the product package (coercive).

The legal protection that can be applied to consumers of financial service institutions is based on the Financial Services Authority Regulation Number 1/POJK.07/2013 concerning Consumer Protection in the Financial Services Sector, which is clearly and firmly regulated in Article 19 as follows:

Article 198: Financial Services Businesses are prohibited from offering products and services to consumers and the public through private communication facilities without the consumers' consent.

As explained in Article 19 of the Financial Services Authority Regulation Number: 1 POJK.07/2013 concerning Consumer Protection in the Financial Services Sector, what is meant by "personal communication facilities" in this paragraph are private communication facilities, such as email, short message system, and voicemail ${ }^{9}$.

Talking about legal protection for consumers, in reality, it certainly has obstacles in implementing consumer protection for violations of the transaction itself. Judging from the examples of cases on the previous page, it is undoubtedly tough to ask for legal protection for transactions that result in losses from the consumer. The following are consumer difficulties:

a) Bureaucracy: With bureaucracy, consumers will find it easy to ask for legal protection because the bureaucracy is a driving machine development and public services. The bureaucracy is significant in realizing excellent public services. However, the fact is that the bureaucracy itself is made difficult. As a result, the services provided are profit-oriented, so that it is difficult for consumers to get legal protection services themselves.

b) Data Leakage: With this data leak, it is difficult for consumers to ask for legal protection because it seems as if the consumer himself voluntarily gives his data to an irresponsible person. With this data leak, irresponsible actors can freely find our data and only need further confirmation from consumers.

c) Lack of Socialization: The lack of socialization carried out by the Financial Services Authority makes it difficult for Consumers of Financial Services Institutions to know what actions or actions consumers should take. The lack of socialization carried out to the community also resulted in many violations committed by Financial Services Institutions to consumers.

In addition, the weak position of consumers is also caused by, among other things, the existing legal instruments cannot provide a sense of security, the existing laws and regulations are inadequate to directly protect the interests and rights of consumers who should be involved in law enforcement. Feel less assertive. On the other hand, the way of thinking as a business actor is still profit-oriented in the short-term context without paying attention to the interests of consumers who are part of the guarantee for the continuity of the business in the long-term context.

Legal remedies for the settlement process for violations of telephone transactions at Financial Services Institutions can be made on complaints with alleged indications of violations and will be forwarded to the Directorate of Consumer Supervision (DPKS) to the relevant supervisory work unit and cannot be resolved through a facilitation process by DPKS.

Types of sanctions that can be applied by the Financial Services Authority for violations of telephone transactions at Financial Services Institutions, in general, by Article 53 of POJK No.1./POJK .07/2013 concerning Consumer Protection in the Financial Services Sector, sanctions that can be imposed to Financial Services Institutions for violations of consumer protection provisions including violations of telephone transactions at Financial Services Institutions, are as follows: (1) Written warning, (2)

Fines, (3) Restrictions on business activities, (4) Freezing of business activities, (5) Revocation of business licenses.

Sanctions to Financial Services Institutions (LJK) for non-performance of the obligations of Financial Services Institutions in the context of consumer protection refer to POJK Number: 1/POJK.07/2013 concerning Consumer Protection in the Financial Services Sector, which is a reduction from Law Number: 21 of 2011 concerning Financial Services Authority. As for the process of

\footnotetext{
${ }^{8}$ Article 19 Regulation of the Financial Services Authority Number: 1/POJK.07/2013 concerning Consumer Protection in the Financial Services Sector

${ }^{9}$ Elucidation of Article 19 of the Financial Services Authority Regulation Number: 1/POJK.07/2013 concerning Consumer Protection in the Financial Services Sector
} 
Legal Protection on Violations Related to Consumer Financial Services in Transactions Through the Phone Media (Study of Financial Services Authority Regulation Number 1/Pojk.07/2013)

implementing sanctions (execution) that have been applied and have legal force, especially at the Jakarta Regional I Office, no sanctions have been given to Financial Services Institutions. If any, the Financial Services Authority will impose sanctions by the Financial Services Authority Regulations above. And regarding legal remedies and or objections that can be made by the Financial Services Institutions on the application of sanctions by the OJK, if any,

The relationship between the Financial Services Authority (OJK) and other institutions for implementing executions is carried out by coordinating with related institutions if necessary, for example, through the Investment Alert Task Force.

\section{CONCLUSION}

Whereas legal protection for consumers of Financial Services Institutions in telephone transactions has been affirmed, and it is also stated regarding the rights and obligations of consumers and business actors as stipulated in Articles 4, 5, 6, 7, and Article 8 of Law Number 8 of 1999 concerning consumer protection. Moreover, based on the Financial Services Authority Regulation Number 1 /POJK.07/2013 concerning Consumer Protection in the Financial Services Sector, as clearly and firmly regulated in Article 19. The Consumer Protection Act also positions itself as a general law (lex generalis) against Other, more specific laws (lex species), such as those related to Law No. 21 of 2011 concerning the Financial Services Authority (OJK) and more specifically related to the Regulation of the Financial Services Authority Number: 1 /POJK.

Efforts made to provide legal protection to consumers for obstacles that arise in Financial Services Institutions for violations committed by telephone are based on the Financial Services Authority Regulation Number: 1/POJK.07/2013 concerning Consumer Protection in the Financial Services Sector. Indications of violations that will be forwarded to the Directorate of Consumer Supervision (DPKS) to the relevant supervisory work unit but cannot be resolved through facilitation of the Directorate of Consumer Supervision (DPKS) as stated in Article 40 and Article 41 of the Financial Services Authority Regulation Number: 1/POJK.07/2013.

\section{REFRENCES}

Book :

1) Nasution. AZ, Law and Consumers: Socio-Economic and Legal Review on Indonesian Consumer Protection, Sinar Harapan Pustaka, Jakarta, 1995, p. 64.

2) Saragih, Bungaran, Futures Exchange Prospects in Agricultural Development, BAPPEBTI, Jakarta, 2004 , p. 19

3) Raharjo, Satjipto, Legal Studies, Bandung: PT. Image of Aditya Bakti, 2000, p. 53

4) Shidarta, Indonesian Consumer Protection Law, PT. Grasiondo, Jakarta, 2006, p. 61

Legislation:

1) Article 19 Financial Services Authority Regulation Number: 1/POJK.07/2013 concerning Consumer Protection in the Financial Services Sector 